\title{
特集 運動療法の可能性
}

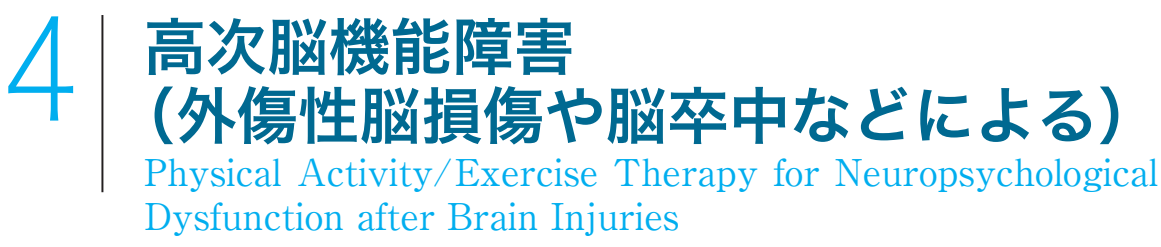

先嵭 章*1,2

Akira Senzaki

Key words : 運動/体育／高次脳機能障害／神経心理／注意/ワーキングメモリー

脳損傷による高次脳機能障害により, 身体障害がなくてもしばしば活動や参加に難が生じる. 身体活動（運動療法）について, (1)身体活動（運動療法）は脳そのものに働き認知機能を改 善させ得ること，(2)健常者において運動療法を定期的に継続することでワーキングメモリー が向上し得ること, (3)運動療法が外傷性脳損傷や脳卒中などの脳損傷者において注意や記 憶, 空間認知といった認知能力を高める可能性があること, (4)経過の長い比較的若い脳損傷 者の人たちに体育や運動療法による介入の余地があることを, 無作為抽出試験による研究論 文を中心にレビューした，発症後数力月以上すでに経過した脳卒中者や脳外傷者に対して, 週 3 回程度, 1 回 1 時間程度, 2〜6 カ月間の運動プログラム, 有酸素運動を行うと, 主に 注意力や記憶力の向上が得られる可能性がある.

\section{はじめに}

比較的経過が長く自宅以外に生活の場がない高 次脳機能障害者が，健康増進施設での体育すなわ ち身体活動（physical activity）を定期的に行うう ちに，日常生活上の記憶力や注意力がわずかだが 向上し, 結果として社会適応がよくなる事実を, 著 者は経験してきた1)。それが身体活動による認知 機能の向上によるものなのか, 体力を向上させ意 欲・活動を賦活することによるものなのか，あるい は集団活動の社会心理的な効果によるものなのか, それらが混合したものなのか, エビデンスは明らか でない.

\footnotetext{
* 1 東京福祉大学社会福祉学部

（テ372-0831 群馬県伊勢崎市山王町 2020-1）

E-mail : senzakiakira@gmail.com

$* 2$ 埼玉県総合リハビリテーションセンター神経科
}

このうち社会心理的な効力については, その場 に固有な環境に由来する要因が大きく，また個別 性があり科学的な証明が難しい. 医学誌である本 誌においては, 身体運動（運動療法）の，まずは医 学・生物学的な効力についてのエビデンスを提示 すべきであろう，そこで本稿では，(1)身体活動（運 動療法) が認知機能を改善する生物学的根拠, (2) 健常者でのワーキングメモリーへの神経心理学的 効果, (3)脳損傷者への効果, そして(4)自験例での 体育活動においての検討に絞って言及したい.

\section{運動療法は脳そのものに 働き認知機能を改善させ得る}

(1)身体活動（運動療法）が認知機能を改善する 医学・生物学的根拠について，運動療法により体 力が向上し，その結果として脳機能の向上がみら れるのであろうか. この点について, 中年以後 $(55$ 
表 1 身体活動（運動療法）が認知機能の維持・向 上に有効であり得る根拠（文献 4 の内容を筆者 がまとめた）

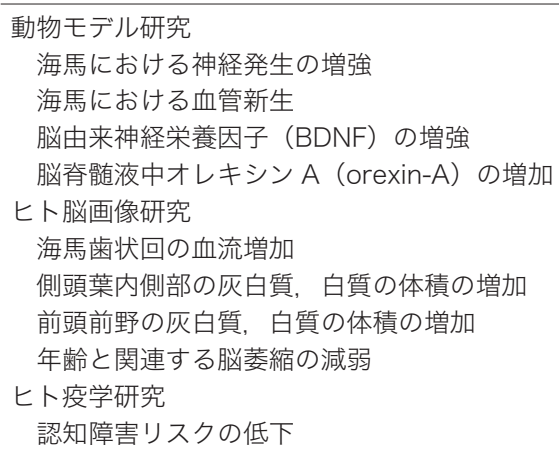

BDNF : brain-derived neurotrophic factor

歳以上）の健康人に対する運動療法のレビュー 2,3$)$ が興味深い. Young ら (2015) ${ }^{3)}$ は, 身体運動と認 知機能との関係を検討した 754 論文の中から, 厳 密な randomized controlled trial（無作為抽出試 験, RCT）を行って, しかも運動療法実施群が未害 施群に比べて maximal oxygen consumption $\left(\mathrm{VO}_{2}\right.$ max）が有意に向上していた 12 論文を仔細に検討 した. すると意外なことに, $\mathrm{VO}_{2} \max$ の向上すな わち運動持久力の向上は, 認知機能の改善に必ず しも直接結びっくわけではないことが判明したとい う。これは逆に, 運動療法が持久力の向上とは別 の何らかの機序で, 脳機能そのものの働きを高め ている可能性を示唆する.

有酸素運動を主とした身体活動（physical activity）を適度に定期的に行うことが，脳に何らか の変化をもたらし, 認知機能の維持や向上に結び つくのではないのか. そのような運動療法の脳へ の直接の効果を検証した研究は, 動物実験も含め て多くある. Chieffi ら (2017) ${ }^{4)}$ は, 加齢に関連し た認知機能の低下を身体運動（運動療法）は予防 し得るという仮説に基づいて, 根拠となり得る 97 の論文をレビューした，有酸素運動を主とした身 体運動が, 加齢と関連する認知機能の低下に対抗 し得る根拠を整理すると表 1 のようになる.
動物実験では, 有酸素運動は脳血流を増加させ, 海馬における脳由来神経栄養因子（brain-derived neurotrophic factor : BDNF) や血管新生, 成長因 子を増加させることが確認されている ${ }^{4)}$. ヒトの脳 画像研究では, 側頭葉内側部の血流や体積の増加, あるいは前頭前野の体積の増加が確認されてい $ろ^{4)}$.

\section{健常者において運動療法を定 期的に継続することでワーキ ングメモリーが向上し得る}

(2)健常者でのワーキングメモリーへの神経心理 学的効果について. Rathore ら (2017) ${ }^{5)}$ は, 健常 者のワーキングメモリーに対する運動療法の効果 を検証した論文をレビューした。これは 2009〜 2016 年の間の 7,345 論文の中から厳密な RCT 行っていて信頼性が十分に認められる 15 論文を詳 しく検討したものである. 表 2 にその 15 論文を一 覧表にした。表 2 上半分の 8 論文 ${ }^{6-13)}$ が 1 回 60 分前後の有酸素運動を中心とする身体運動を, 週 2〜3 回, 1〜6 カ月間継続した場合の検証である. 介入の効果が必ずしも全論文で認められているわ けではないが，8論文中 5 論文では神経心理学的 検査において有意差を認めた。健常者にて運動療 法を習慣化することがワーキングメモリーを向上さ せ得ると Rathore らは結論している5).

表 2 下半分の 7 論文 ${ }^{14-20)}$ が単発の運動療法の 効果を検証したものである。こちらは若い児童・ 学生を対象とした検討も含まれる. 数唱が向上し たものもあれば変化がなかったものもあり, 評価は 分かれる.

\section{脳損傷者において, 認知能力を 高める可能性}

(3)脳損傷者への効果について. 運動療法が, 外 傷性脳損傷や脳卒中などの脳損傷者において, 認 
表 2 健常者のワーキングメモリーに対する運動の効果（上段 8 論文〔文献 6～13) は複数期間・複数回実施, 下段 7 論文〔文献 14〜20) は単発実施で評価)

\begin{tabular}{|c|c|c|c|c|c|c|c|c|c|c|}
\hline No. & $\begin{array}{l}\text { 論文著者, } \\
\text { 発行年 }\end{array}$ & $\begin{array}{l}\text { 文献 } \\
\text { 番号 }\end{array}$ & $\begin{array}{l}\text { 研究の質 } \\
\text { 比較対照 } \\
\text { 群 }\end{array}$ & 対象（除外基準） & $\begin{array}{l}\text { 症例数 } \\
\text { (人) } \\
\text { 女性率 } \\
\text { (\%) }\end{array}$ & $\begin{array}{l}\text { 平均年 } \\
\text { 齢(歳) }\end{array}$ & $\begin{array}{l}\text { 神経心理学的 } \\
\text { 評価 }\end{array}$ & 運動の内容 & $\begin{array}{l}\text { 期間と回数, } 1 \text { 回あ } \\
\text { たりの時間, 場所 }\end{array}$ & $\begin{array}{l}\text { 効果（介入の結 } \\
\text { 果, ワーキング } \\
\text { メモリーは向上 } \\
\text { したか?） }\end{array}$ \\
\hline 1 & $\begin{array}{l}\text { Brown, } \\
2009\end{array}$ & 6) & $\begin{array}{l}\text { RCT } \\
\text { 非運動群 }\end{array}$ & $\begin{array}{l}\text { 運動に支障ある神経系, 心血管 } \\
\text { 系, 筋骨格系の疾患をもつ者, } \\
\text { すでに exercise class に参加し } \\
\text { ている者やMMSE が } 20 \text { 未満 } \\
\text { も除外 }\end{array}$ & $\begin{array}{l}154 \\
88\end{array}$ & $\begin{array}{l}79.6 \\
62 \sim 95\end{array}$ & 順唱逆唱 & $\begin{array}{l}\text { 抵抗運動, バ } \\
\text { ランス訓練, } \\
\text { 運動 fitness }\end{array}$ & $\begin{array}{l}6 \text { 力月間, 週 } 2 \text { 日, } \\
60 \text { 分 } \\
\text { 退職者村にてグ } \\
\text { ループで }\end{array}$ & 効果なし \\
\hline 2 & $\begin{array}{l}\text { Fisher, } \\
2011\end{array}$ & 7) & $\begin{array}{l}\mathrm{RCT} \\
\text { 技能開発 } \\
\text { 課題群 }\end{array}$ & $\begin{array}{l}\text { 認知機能障害児や身体障害児は } \\
\text { 除外 } \\
\text { 反応時間が } 200 m \text { 秒未満で真 } \\
\text { 摰な反応でない児童も除外 }\end{array}$ & $\begin{array}{l}64 \\
55\end{array}$ & 6.1 & $\begin{array}{l}\text { CANTAB Spa- } \\
\text { tial Working } \\
\text { Memory } \\
\text { Errors }\end{array}$ & $\begin{array}{l}\text { 有酸素運動 } \\
\text { (中等度〜強 } \\
\text { 度) }\end{array}$ & $\begin{array}{l}10 \text { 週 間, 週 } 2 \text { 日, } \\
120 \text { 分 } \\
\text { グループで }\end{array}$ & 向上した \\
\hline 3 & $\begin{array}{l}\text { Haripra- } \\
\text { sad, } 2013\end{array}$ & 8) & $\begin{array}{l}\mathrm{RCT} \\
\text { 技能課題 } \\
\text { 実施群 }\end{array}$ & $\begin{array}{l}\text { 認知症者, 神経疾患患者, 脳卒 } \\
\text { 中者, うつ病者を除外 }\end{array}$ & $\begin{array}{l}120 \\
83\end{array}$ & $\begin{array}{l}75.74 \\
60 \sim\end{array}$ & $\begin{array}{l}\text { Wechsler } \\
\text { Memory Scale } \\
\text { の数唱, タッピ } \\
\text { ング Span }\end{array}$ & ヨガ & $\begin{array}{l}6 \text { カ月間, } 1 \text { カ月間 } \\
\text { は毎日, 他の期間 } \\
\text { は毎週老人施設に } \\
\text { て }\end{array}$ & 向上した \\
\hline 4 & $\begin{array}{l}\text { Gothe, } \\
2014\end{array}$ & 9) & $\begin{array}{l}\text { RCT } \\
\text { ストレッ } \\
\text { チと筋力 } \\
\text { 増強訓練 } \\
\text { 群 }\end{array}$ & $\begin{array}{l}6 \text { カ月以内に転入後の者は除外 } \\
\text { すでに現在ヨガを行っている者 } \\
\text { は除外 }\end{array}$ & $\begin{array}{l}118 \\
83\end{array}$ & $\begin{array}{l}62.0 \\
55 \sim 79\end{array}$ & $\begin{array}{l}\text { N-back test } \\
\text { (1-back, } \\
\text { 2-back) }\end{array}$ & ヨガ & $\begin{array}{l}8 \text { 週間, 週 } 3 \text { 日, } 60 \\
\text { 分 } \\
\text { コミュニティーセ } \\
\text { ンターにてグルー } \\
\text { プで }\end{array}$ & 向上した \\
\hline 5 & $\begin{array}{l}\text { Nouchi, } \\
2014\end{array}$ & 10) & $\begin{array}{l}\mathrm{RCT} \\
\text { 次回以降 } \\
\text { 参加予定 } \\
\text { 群 }\end{array}$ & $\begin{array}{l}\text { MMSE } 26 \text { 未満は除外. 認知機 } \\
\text { 能に影響のある服薬をしている } \\
\text { 者は除外. 中枢神経系の疾患は } \\
\text { 除外. ジムやへルスクラブに参 } \\
\text { 加している者や他の運動活動に } \\
\text { 参加している者は除外 }\end{array}$ & $\begin{array}{l}64 \\
\text { 性別不 } \\
\text { 明 }\end{array}$ & $\begin{array}{l}75.74 \\
60 \sim\end{array}$ & $\begin{array}{l}\text { 順唱 } \\
\text { 逆唱 }\end{array}$ & $\begin{array}{l}\text { 有酸素運動, } \\
\text { ストレッチ, } \\
\text { 筋力増強訓練 } \\
\text { (中等度〜強 } \\
\text { 度) }\end{array}$ & $\begin{array}{l}4 \text { 週間, 週 } 3 \text { 日, } 48 \\
\text { 分 } \\
\text { 仙台市にてグル- } \\
\text { プで }\end{array}$ & 効果なし \\
\hline 6 & $\begin{array}{l}\text { Vaughan, } \\
2014\end{array}$ & 11) & $\begin{array}{l}\mathrm{RCT} \\
\text { 次回以降 } \\
\text { 参加予定 } \\
\text { 群 }\end{array}$ & $\begin{array}{l}\text { 認知症, パーキンソン病, 最近 } \\
\text { の頭部外傷の既往者は除外 }\end{array}$ & $\begin{array}{l}49 \\
100\end{array}$ & $\begin{array}{l}69.0 \\
65 \sim 75\end{array}$ & $\begin{array}{l}\text { Letter- } \\
\text { Number } \\
\text { Sequencing }\end{array}$ & $\begin{array}{l}\text { 有酸素運動, } \\
\text { ストレッチ, } \\
\text { 筋力増強訓練 }\end{array}$ & $\begin{array}{l}16 \text { 週 間, 週 } 2 \text { 日, } \\
60 \text { 分 } \\
\text { コミュニティーセ } \\
\text { ンターにてグルー } \\
\text { プで }\end{array}$ & 向上した \\
\hline 7 & $\begin{array}{l}\text { Albinet, } \\
2016\end{array}$ & 12) & $\begin{array}{l}\text { RCT } \\
\text { ストレッ } \\
\text { チ柔軟運 } \\
\text { 動群 }\end{array}$ & $\begin{array}{l}\text { MMSE が } 26 \text { 未満は除外. 心肺 } \\
\text { 系や認知機能に影響を与える服 } \\
\text { 薬をしている者は除外. 心肺疾 } \\
\text { 患や神経疾患の既往者は除外 }\end{array}$ & $\begin{array}{l}41 \\
72\end{array}$ & $\begin{array}{l}66 \\
60 \sim 80\end{array}$ & $\begin{array}{l}\text { N-back test } \\
(2-\text { back }) \text { 空 } \\
\text { 間および言語 } \\
\text { の running } \\
\text { span 課題 }\end{array}$ & $\begin{array}{l}\text { 水中エアロ } \\
\text { ビック, 水泳 } \\
\text { (中等度〜強 } \\
\text { 度) }\end{array}$ & $\begin{array}{l}5 \text { カ月間, 週 } 2 \text { 日, } \\
60 \text { 分 } \\
\text { コミュニティーセ } \\
\text { ンターにてグルー } \\
\text { プで }\end{array}$ & 向上した \\
\hline 8 & $\begin{array}{l}\text { Chapman, } \\
2016\end{array}$ & 13) & $\begin{array}{l}\text { RCT } \\
\text { 次回以降 } \\
\text { 参加予定 } \\
\text { 群 } \\
\end{array}$ & $\begin{array}{l}\text { 神経疾患, 精神疾患の既往者は } \\
\text { 除外. 高卒未満の学歴, 知的に } \\
\text { 正常範囲にない者は除外. うつ } \\
\text { や肥満者は除外 }\end{array}$ & $\begin{array}{l}67 \\
73\end{array}$ & $\begin{array}{l}63.5 \\
56 \sim 75\end{array}$ & Reading span & $\begin{array}{l}\text { 有酸素運 動 } \\
\text { (中等度〜強 } \\
\text { 度) }\end{array}$ & $\begin{array}{l}12 \text { 週間, 週 } 3 \text { 回, } 60 \\
\text { 分 } \\
\text { 実験室で個別で }\end{array}$ & 効果なし \\
\hline 9 & $\begin{array}{l}\text { Budde, } \\
2010\end{array}$ & 14) & $\begin{array}{l}\mathrm{RCT} \\
\text { ランニン } \\
\text { グしない } \\
\text { 群 }\end{array}$ & $\begin{array}{l}\text { 心身に障害がある者は除外. 精 } \\
\text { 神作用物質使用歴がある者も除 } \\
\text { 外 }\end{array}$ & $\begin{array}{l}60 \\
43\end{array}$ & $\begin{array}{l}14.37 \\
15 \sim 16\end{array}$ & 数唱 & $\begin{array}{l}\text { ランニング } \\
\text { (中等度〜強 } \\
\text { 度) }\end{array}$ & $\begin{array}{l}1 \text { 回, } 12 \text { 分 } \\
400 \mathrm{~m} \text { トラックで } \\
\text { グループで }\end{array}$ & $\begin{array}{l}\text { 向上はするが, } \\
\text { ごくわずかの効 } \\
\text { 果 }\end{array}$ \\
\hline 10 & $\begin{array}{l}\text { Chang, } \\
2011\end{array}$ & 15) & $\begin{array}{l}\text { RCT } \\
\text { 運動なし } \\
\text { 健康教育 } \\
\text { 受講群 }\end{array}$ & $\begin{array}{l}\text { 有酸素運動に明らかなリスクの } \\
\text { ある者は除外 }\end{array}$ & $\begin{array}{l}42 \\
69\end{array}$ & 21.97 & $\begin{array}{l}\text { Tower of Lon- } \\
\text { don }\end{array}$ & $\begin{array}{l}\text { 自転車エルゴ } \\
\text { メータによる } \\
\text { 有 酸 素 運 動 } \\
\text { (中等度〜 強 } \\
\text { 度) }\end{array}$ & $\begin{array}{l}1 \text { 回, } 30 \text { 分 } \\
\text { 実験室で個別で }\end{array}$ & 向上した \\
\hline 11 & $\begin{array}{l}\text { Hogan, } \\
2013\end{array}$ & 16) & $\begin{array}{l}\mathrm{RCT} \\
\text { 健康教育 } \\
\text { 群 }\end{array}$ & MMSE が 22 未満は除外 & $\begin{array}{l}144 \\
49\end{array}$ & $\begin{array}{l}50.79 \\
19 \sim 93\end{array}$ & $\begin{array}{l}\text { N-back test } \\
(2-\text { back })\end{array}$ & $\begin{array}{l}\text { 自転車エルゴ } \\
\text { メータ（中等 } \\
\text { 度） }\end{array}$ & $\begin{array}{l}1 \text { 回, } 15 \text { 分 } \\
\text { 実験室で個別で }\end{array}$ & $\begin{array}{l}\text { 反応時間が短縮 } \\
\text { した }\end{array}$ \\
\hline 12 & Chen, 2014 & 17) & $\begin{array}{l}\mathrm{RCT} \\
\text { 健康教育 } \\
\text { 群 }\end{array}$ & $\begin{array}{l}\text { WISC-IVでのIQ } 90 \text { 以下は除 } \\
\text { 外. 注意欠損多動症児は除外. } \\
\text { 左利き児, 色盲児, 精神科薬服 } \\
\text { 用児も除外 }\end{array}$ & $\begin{array}{l}87 \\
48\end{array}$ & $\begin{array}{l}\text { 小学 } 3 \\
\text { 年 } \\
9.18 \\
\text { 小学 } 5 \\
\text { 年 } \\
11.11\end{array}$ & $\begin{array}{l}\text { N-back test } \\
\text { (2-back) } \\
\text { modified }\end{array}$ & $\begin{array}{l}\text { ジョギング } \\
\text { (中等度) }\end{array}$ & $\begin{array}{l}1 \text { 回, } 30 \text { 分 } \\
\text { 学校でグループで }\end{array}$ & $\begin{array}{l}5 \text { 年生の群のみ } \\
\text { で向上 }\end{array}$ \\
\hline 13 & $\begin{array}{l}\text { Bantoft, } \\
2016\end{array}$ & 18) & $\begin{array}{l}\text { RCT } \\
\text { 着席群 }\end{array}$ & $\begin{array}{l}\text { 妊娠者, 心疾患者, 慢性腰痛者 } \\
\text { は除外 }\end{array}$ & $\begin{array}{l}45 \\
71\end{array}$ & 22.67 & $\begin{array}{l}\text { 順唱 } \\
\text { 逆唱 }\end{array}$ & $\begin{array}{l}\text { トレッドミル } \\
\text { にて歩行（軽 } \\
\text { 度） }\end{array}$ & $\begin{array}{l}1 \text { 回, } 60 \text { 分 } \\
\text { 実験室で個別で }\end{array}$ & 効果なし \\
\hline 14 & $\begin{array}{l}\text { Basso, } \\
2016\end{array}$ & 19) & $\begin{array}{l}\text { RCT } \\
\text { ビデオ鑑 } \\
\text { 賞群 }\end{array}$ & $\begin{array}{l}6 \text { カ月以内に手術歴がある者, } \\
\text { 薬物やアルコール乱用, 精神疾 } \\
\text { 患の既往者は除外. 認知機能に } \\
\text { 影響のある服薬をしている者も } \\
\text { 除外 }\end{array}$ & $\begin{array}{l}92 \\
60\end{array}$ & $\begin{array}{l}22.21 \\
18 \sim 35\end{array}$ & 数唱 & $\begin{array}{l}\text { 自転車エルゴ } \\
\text { メータによる } \\
\text { 有酸 素 運 動 } \\
\text { (強度) }\end{array}$ & $\begin{array}{l}1 \text { 回, } 50 \text { 分 } \\
\text { 実験室で個別で }\end{array}$ & 向上した \\
\hline 15 & $\begin{array}{l}\text { Howie, } \\
2015\end{array}$ & 20) & $\begin{array}{l}\text { RCT } \\
\text { 着席して } \\
\text { のクラス } \\
\text { 活動 }\end{array}$ & （記載なし） & $\begin{array}{l}96 \\
65\end{array}$ & $\begin{array}{l}10.7 \\
9 \sim 12\end{array}$ & 数唱 & $\begin{array}{l}\text { 有酸素運動 } \\
\text { (中等度〜 強 } \\
\text { 度) }\end{array}$ & $\begin{array}{l}1 \text { 回, } 10 \text { 分 } \\
\text { 学校でグループで }\end{array}$ & 効果なし \\
\hline
\end{tabular}

RCT : randomized controlled trial（無作為抽出試験), CANTABC : Cambridge Neuropsychological test automated battery, MMSE : Mini Mental State Examination, N-back test とは Continuous Performance Task のこと. WISC-IV : Wechsler Intelligence Scale for Children-Fourth Edition 
知能力を高める可能性を証明しようとした多くの 研究があり, Vanderbeken ら $(2017)^{21)}$ がレビュー している。これは，脳損傷者に対する身体運動に ついての 936 論文の中から研究デザインや評価法, 統計処理がきちんと記述されていて信頼がおけ, 検証が可能で検討に值する 13 論文を中心にレ ビューしている，このレビュー内の表をわかりやす く改変し, 表 3 「脳損傷者の神経心理学的障害に対 する運動療法の効果」として示す.

外傷性脳損傷者を対象とした 2 論文 ${ }^{23,24)}$ は受傷 後に比較的時間が経ってからの介入である.うち Chin ら (2015) ${ }^{24)}$ は症例数が少ない中での検討で あるが, 有酸素運動が認知機能にプラスの影響を 及ぼす可能性を示唆している.

一方, 脳卒中者においては対象者が, 発症後 1 カ月以内の比較的早期に介入した場合 $25,26,31)$ と 発症後数力月以上経過してからの場合 ${ }^{27-30)}$ とに分 けられる. Functional Independence Measure (FIM) 認知項目といったおおおおな観察評価では, 早期から介入した場合 ${ }^{25)}$ も数力月以上経過後介入 した場合 ${ }^{27)} も$, 運動療法の効果は証明できなかっ たようである. 一方, いくつかの文献 ${ }^{30,32-34)}$ の細 かな神経心理学的検査での検討では, 数力月以上 経過後介入した場合, 運動療法群で有意な認知能 力の改善を認めている.

以上の論文を総合すると, 発症後数週〜数力月 が経過した脳卒中者や脳外傷者に対して, 週 3 回 程度, 1 回 1 時間程度, 2 6 カ月間の運動プログ ラムを行うと, 主に注意力や記憶力の向上が得ら れうる。

\section{記憶障害を認める脳損傷者に 適度な体育（運動療法）を行う 意義}

(4)自験例での体育活動においての検討につい て. 日本において脳損傷者は, 発症数力月経過し
回復期を過ぎると, 作業療法士や理学療法士, 言 語聴覚士による医療的なリハビリテーションプロ グラムを，医療保険の枠組みでは綿密に実施する ことが難しくなる。これは，身体障害が目立たない 高次脳機能障害者の場合には，なおさらであろう. 記憶障害, 注意障害, 遂行機能障害あるいは情動 の問題による日常生活上の困難は, しばしば病院 から在宅生活に移行してから顕在化する。 そして, 社会的な適応に至るまでに多くの時間と労力が必 要になる.

運動機能に大きな問題がない脳損傷者の場合に は, 自宅で生活しながら, 家族の介助あるいは移動 支援により地域事業所や障害者支援施設などに通 所し，日中の活動の場を広げ，地域での生活ある いは (保護的) 就労をめざす. しかし, 年齢が比較 的若くて, 高齢者を対象とした地域での活動の場 に適応できない場合, あるいは神経心理学的機能 障害の程度が重い場合には，しばしば自宅以外の 場所に活動の場を得ることができないという現実 がある. 本人も家族もさらに社会から孤立してし まう.

筆者は, 発症より数年経過したが自宅以外に活 動の場がそしい，記憶障害を主症状とする脳損傷 者（外傷性脳損傷, 脳卒中, 低酸素脳症など） 35 名に健康増進施設での体育活動を週 1 回数力月以 上行った結果, 体育活動を継続した群 $(\mathrm{n}=19)$ は, 休止した群 $(\mathrm{n}=16)$ に比較して Functional Assessment Measure（FAM）「注意」の改善度が有 意 $(\mathrm{p}=0.048)$ であったことを示した1).

i ）日本の社会福祉制度において介護保険を利 用できない若い脳損傷者の人たち, ii ）通常の作 業や机上の認知向上プログラムには意欲をもてな い人たち, iii）同様の仲間との交流の中で身体的 な体力の向上を目的とすることに意欲をもてる人 たち, には, 体育, 広い意味での運動療法の介入が 有効であろう。 


\section{表 3 脳損傷者の神経心理学的障害に対する運動療法の効果}

\begin{tabular}{|c|c|c|c|c|c|c|c|c|}
\hline \multirow{2}{*}{ No. } & \multirow{2}{*}{$\begin{array}{c}\text { 論文筆者, } \\
\text { 発行年 }\end{array}$} & \multirow{2}{*}{$\begin{array}{l}\text { 文献 } \\
\text { 番号 }\end{array}$} & \multirow{2}{*}{$\begin{array}{l}\text { 研究 } \\
\text { の質 }\end{array}$} & \multirow{2}{*}{ 対象 } & 例数 (人) & 平均年齢(歳) & 発症後の (平均) 期間 & \multirow{2}{*}{ 神経心理学的評価 } \\
\hline & & & & & \multicolumn{3}{|c|}{ 運動介入群/コントロール群 } & \\
\hline 1 & $\begin{array}{l}\text { Bateman, } \\
2001\end{array}$ & 22) & RCT & 脳損傷 & $78 / 79$ & $41.7 / 44.7$ & 22.2 週/25.5 週 & FIM 認知項目 \\
\hline 2 & $\begin{array}{l}\text { McMillian, } \\
2002\end{array}$ & 23) & $\mathrm{RCT}$ & $\begin{array}{l}\text { 外傷性 } \\
\text { 脳損傷 }\end{array}$ & 145 & $\begin{array}{l}31.4 / 34.6 / \\
36.2\end{array}$ & $3 \sim 12$ 月 & $\begin{array}{l}\text { TEA } \\
\text { AMIPB } \\
\text { TMT A/B } \\
\text { PASAT }\end{array}$ \\
\hline 3 & Chin, 2015 & 24) & CT & $\begin{array}{l}\text { 外傷性 } \\
\text { 脳損傷 }\end{array}$ & 9 & 33.3 & 4.0 年 & $\begin{array}{l}\text { TMT A/B } \\
\text { RBANS }\end{array}$ \\
\hline 4 & $\begin{array}{l}\text { Nilsson, } \\
2001\end{array}$ & 25) & RCT & 脳卒中 & $36 / 37$ & $54 / 56$ & 22 日/17日 & FIM 認知項目 \\
\hline 5 & Fang, 2003 & 26) & $\mathrm{RCT}$ & 脳卒中 & $78 / 78$ & $65.49 / 61.8$ & 1 週末満 & MMSE \\
\hline
\end{tabular}

Studenski, 27） RCT 脳卒中 50/50 68.5/70.4 77.5日/74.1 日
2005

\begin{tabular}{|c|c|c|c|c|c|c|c|c|}
\hline 7 & $\begin{array}{l}\text { Ploughman, } \\
2008\end{array}$ & 28) & $\mathrm{RCT}$ & 脳卒中 & 21 & 61.4 & 20.1 月 & $\begin{array}{l}\text { TMT A/B } \\
\text { SDS (WAIS- III) } \\
\text { PASAT }\end{array}$ \\
\hline 8 & $\begin{array}{l}\text { Quaney, } \\
2009\end{array}$ & 29) & $\mathrm{RCT}$ & 脳卒中 & $20 / 20$ & $64.10 / 58.96$ & 4.62 年/5.11 年 & $\begin{array}{l}\text { WCST } \\
\text { SCWT } \\
\text { TMT A/B } \\
\text { PGFM }\end{array}$ \\
\hline 9 & $\begin{array}{l}\text { Moore, } \\
2015\end{array}$ & 30) & RCT & 脳卒中 & $20 / 20$ & $68 / 70$ & 21 月/16月 & ACE-R \\
\hline 10 & Pyöriä, 2007 & 31) & СCT & 脳卒中 & $40 / 40$ & $72 / 72$ & 1 週間未満 & $\begin{array}{l}\text { 言語 (BNT, VFT, TT), 記 } \\
\text { 憶 (ADAS-R, WMS), 視空 } \\
\text { 間能力 (ADAS-CP, CPT, } \\
\text { GCT), 視 覚 注 意 (LBT, } \\
\text { LCT) }\end{array}$ \\
\hline
\end{tabular}

$\begin{array}{llllll} & \text { El-Tamawy, 32) } \\ 2014 & \text { CCT 脳卒中 } & 15 / 15 & 48.4 / 49.67 & 3 \sim 18 \text { 月 } & \text { ACE-R }\end{array}$

\begin{tabular}{|c|c|c|c|c|c|c|c|c|}
\hline 12 & $\begin{array}{l}\text { Kluding, } \\
2011\end{array}$ & 33) & $\mathrm{CT}$ & 脳卒中 & 11 & 63.7 & 50.4 月 & $\begin{array}{l}\text { Digit Span backwards } \\
\text { Flanker tests }\end{array}$ \\
\hline 13 & $\begin{array}{l}\text { Marzolini, } \\
2013\end{array}$ & 34) & $\mathrm{CT}$ & 脳卒中 & 45 & 63.6 & 74.0 週 & $\begin{array}{l}\text { モントリオール認知評価 } \\
\text { (MoCA) }\end{array}$ \\
\hline
\end{tabular}

CCT, CT とも臨床試験で無作為化試験である

RCT : randomized controlled trial (無作為抽出試験), ACE-R : Addenbrooke's Cognitive Examination Revised, ADAS (CP, R) : Alzheimer's Disease Assessment Scale (Constructional Praxis, Recall), AMIPB : Adult Memory and Information Processing Battery, BNT: Boston Naming Test, CPT : Clock Perception Test, GCT : Greek Cross Test, LBT : Line Bisection Test, LCT : Letter Cancellation Test, MMSE : 


\section{表 3 つづき}

\begin{tabular}{|c|c|c|c|}
\hline \multirow{2}{*}{ No. } & 運動の内容 & 期間と回数, & \multirow{2}{*}{ 効果（介入の結果） } \\
\hline & 運動介入群/コントロール群 & 1 回あたりの時間 & \\
\hline 1 & $\begin{array}{l}\text { 有酸素運動（エルゴメータ）/ } \\
\text { リラクゼーション }\end{array}$ & $\begin{array}{l}12 \text { 週間, 週 } 3 \text { 日, } \\
30 \text { 分 }\end{array}$ & $\begin{array}{l}\text { 有酸素運動群, リラクゼーション群の } 2 \text { 群で, 開始 } 12 \text { 週 } \\
\text { 後, } 6 \text { カ月後とも有意差なし }\end{array}$ \\
\hline
\end{tabular}

身体活動と自宅での課題/

2 注意訓練と自宅での課題/ 介入なし
4 週間, 週 7 日, 身体活動群, 注意訓練群, 介入なし群の 3 群で, 開始 1 力 45 分
3 有酸素運動（トレッドミル）
12 週間, 週 3 日, 30 分
プログラム終了時は, 開始時に比べて有意に RBANS 総点が 高かった $(p=0.009)$.下位項目では, 言語 $(p=0.043)$ ，空間 認知と構成 $(p=0.004)$, 遅延再生 $(p=0.003)$ が有意に向上し ていた. TMT A $(p=0.007), B(p=0.011)$ も有意に改善した 歩行訓練群, トレッドミル群の 2 群に, 2 カ月時, 10 カ月

8 週間, 週 5 日 30 分 時とも有意差を認めなかった。両群とも同様の改善（ $p<$ 0.001）を認めた

4 週間，週 5 日，早期理学療法追加群と通常ケアのみ群の 2 群で 30 日後，6 45 分 カ月後に有意差なし

5 通常ケアのみ（理学療法士の介入 なし)

自宅での運動プログラム（有酸素 運動, 筋カトレーニング, バラン

6 ス)/

通常ケア $+1 / 2$ 週に 30 分のスタッ

12 週間, 週 3 日, 通常ケア群と運動プログラム群とで, 12 週時, 9 力月時で 90 分 有意差なし

フ訪問

最大心拍数の $70 \%$ あいはボルグ指

7 数13相当の免荷式トレッドミル歩行/ 理学療法士による運動プログラム

20 分間の運動 2 群で有意差を認めなかった

最大心拍数の $70 \%$ での自転車エル

8 ゴメータによる有酸素運動/

自宅での上肢，下肢ストレッチ

8 週間, 週 3 日, TMT による) に 8 週目, 16 週目で有意な違いを認めなかっ 45 分 た. 2 群において, 有酸素運動群が 8 週目で条件付運動学 習 (PGFM) が有意 $(p=0.038)$ に回復していた

さまざまなプログラム（有酸素運

動, 筋力トレーニング, ストレッチ ング，バランス，俊敏性課題)/ 自宅でのストレッチングプログラム

19 週間，週 3 日， $45 \sim 60$ 分

活性化理学療法 (姿勢制御, バラン ス, 有酸素療法, 筋カトレーニン

10 グ)/

伝統的理学療法 (基本動作練習・痤 性抑制）

理学療法後 10〜15 分間休噁し,

1140〜45 分間の有酸素運動（エルゴ X-夕)/

理学療法 25〜30 分のみ

12 有酸素運動（全身反復運動）+下肢 12 週間, 週 3 日, の筋カトレーニング 1 時間 13 有酸素運動, 筋力トレーニング, 自 宅での課題 6 力月, 有酸素運

12 月間, 回数や 時間を決めずに 適宜

8 週間, 週 3 日, $40 \sim 45$ 分

動は週 5 日, 20〜

60 分/筋カトレー

ニングは週1〜2日
さまざまなプログラム群は自宅でのストレッチプログラ ム群に比べて, ACE-R 総得点で有意な違い $(p=0.04)$ を 認めた

活性化理学療法群が伝統的理学療法群に比べて, 記憶の改 善が有意 $(p<0.001)$ であった。活性化理学療法群では, 言語 $(p=0.004)$, 記憶 $(p<0.001)$, 視空間機能 $(p=0.016)$, 視覚注意 $(p=0.012)$ が有意に改善したが, 伝統的理学療 法群では有意差なし

有酸素運動群では未実施群に比較して, ACE-R 総点が有 意に高かった $(p=0.017)$ また, 注意, 記憶, 空間認知の ACE-R 下位項目が有意に高かった（ $p<0.05 ）$

Digit Span backwards にて有意な改善を認めた（ $\mathrm{p}<$ 0.05)

MoCA 総得点 $(p<0.05)$ が有意な改善. 7 下位項中 2 項 目（注意と集中 $p=0.03$, 視空間と遂行 $p=0.002 ）$ に有意 な改善を認めた

Mini Mental State Examination, PASAT: Paced Auditory Serial Addition Test, PGFM: Predictive Grip Force Modulation, RBANS Repeatable Battery for the Assessment of Neuropsychological Status, SCWT : Stroop Color Word Test, SDS (WAIS-III) : Symbol Digit Substitution subtest (Wechsler Adult Intelligence Scale, 3rd edition), TEA : Test of Everyday Attention, TMT : Trail Making Test, TT : Token Test, VFT : Verbal Fluency Test, WCST : Wisconsin Card Sorting Test, WMS : Wechsler Memory Scale 


\section{おわりに}

以上述べてきたように，(1)身体活動（運動療法） は体力を向上させると同時に, 脳そのものに直接 働き認知機能を改善させ得る可能性を示唆するい くつかの知見がある。また，(2)運動療法を定期的 に継続するとワーキングメモリーが向上し得るとす る, 健常者での研究の蓄積がある. 高次脳機能障 害を有する脳損傷者においても, 運動療法のワー キングメモリーに対する効果を期待したい。 さら に, (3)運動療法が外傷性脳損傷や脳卒中などの脳 損傷者において, 注意や記憶, 空間認知に関連す る検査の一部で有意な効果を与えることが確認さ れている. そして, (4)経過の長い比較的若い脳損 傷者たちの認知面の改善のために, 医学的・生物 学的な側面からみても, 体育や運動療法による介 入の余地がある.

もちろん, 行う種目や場所を工夫することによっ て, 集団の中で楽しむ, 活動している今を感じるこ とができる, 達成感を得るといった心理的な効果は 計り知れない. 今後, この方面の研究や実践が日 本でも広まることを願う。

\section{文 献}

1) Senzaki A : Significance of using certified health promotion facilities for people with memory disorders caused by brain injuries. Possibilities of exercise therapy. [in print]

2) Angevaren M, Aufdemkampe G, Verhaar HJ, Aleman A, Vanhees L: Physical activity and enhanced fitness to improve cognitive function in older people without known cognitive impairment. Cochrane Database Syst Rev 2008 ; CD005381

3) Young J, Angevaren M, Rusted J, Tabet N : Aerobic exercise to improve cognitive function in older people without known cognitive impairment. Cochrane Database Syst Rev 2015 ; CD005381

4) Chieffi S, Messina G, Villano I, Messina A, Valenzano A, Moscatelli F, Salerno M, Sullo A, Avola R, Monda V, Cibelli G, Monda M : Neuroprotective Effects of Physical Activity: Evidence from Human and Animal Studies. Front Neurol $2017 ; 8: 188$
5) Rathore A, Lom B : The effects of chronic and acute physical activity on working memory performance in healthy participants : a systematic review with meta-analysis of randomized controlled trials. Syst Rev $2017 ; 6: 124$

6) Brown AK, Liu-Ambrose T, Tate R, Lord SR : The effect of group-based exercise on cognitive performance and mood in seniors residing in intermediate care and self-care retirement facilities: a randomised controlled trial. Br J Sport Med 2009 ; 43 : 608-614

7) Fisher A, Boyle JM, Paton JY, Tomporowski P, Watson C, McColl JH, Reilly JJ : Effects of a physical education intervention on cognitive function in young children : randomized controlled pilot study. BMC Pediatr $2011 ; 11: 97$

8) Hariprasad VR, Koparde V, Sivakumar PT, Varambally S, Thirthalli J, Varghese M, Basavaraddi IV, Gangadhar BN : Randomized clinical trial of yogabased intervention in residents from elderly homes : effects on cognitive function. Indian $\mathrm{J}$ Psychiatry 2013；55 (Suppl 3) : S357-363

9) Gothe NP, Kramer AF, McAuley E : The effects of an 8-week Hatha yoga intervention on executive function in older adults. J Gerontol A Biol Sci Med Sci $2014 ; 69$ : 1109-1116

10) Nouchi R, Taki Y, Takeuchi H, Sekiguchi A, Hashizume H, Nozawa T, Nouchi H, Kawashima R : Four weeks of combination exercise training improved executive functions, episodic memory, and processing speed in healthy elderly people : evidence from a randomized controlled trial. Age (Dordr) 2014; $36: 787-799$

11) Vaughan $S$, Wallis M, Polit D, Steele M, Shum D, Morris N : The effects of multimodal exercise on cognitive and physical functioning and brainderived neurotrophic factor in older women : a randomised controlled trial. Age Ageing $2014 ; 43$ : $623-629$

12) Albinet CT, Abou-Dest A, André N, Audiffren M : Executive functions improvement following a 5 -month aquaerobics program in older adults : role of cardiac vagal control in inhibition performance. Biol Psychol 2016 ; 115 : 69-77

13) Chapman SB, Aslan S, Spence JS, Keebler MW, DeFina LF, Didehbani N, Perez AM, Lu H, D'Esposito M : Distinct brain and behavioral benefits from cognitive vs. physical training : a randomized trial in aging adults. Front Hum Neurosci $2016 ; 10: 338$

14) Budde H, Voelcker-Rehage C, Pietrassyk-Kendziorra S, Machado S, Ribeiro P, Arafat AM : Steroid hormones in the saliva of adolescents after different exercise intensities and their influence on working memory in a school setting. Psychoneuroendocrinology $2010 ; 35: 382-391$

15) Chang YK, Tsai CL, Hung TM, So EC, Chen FT, 
Etnier JL : Effects of acute exercise on executive function : a study with a Tower of London Task. J Sport Exerc Psychol $2011 ; 33: 847-865$

16) Hogan CL, Mata J, Carstensen LL : Exercise holds immediate benefits for affect and cognition in younger and older adults. Psychol Aging $2013 ; 28$ : 587-594

17) Chen AG, Yan J, Yin HC, Pan CY, Chang YK : Effects of acute aerobic exercise on multiple aspects of executive function in preadolescent children. Psychol Sport Exerc $2014 ; 15: 627-636$

18) Bantoft C, Summers MJ, Tranent PJ, Palmer MA, Cooley PD, Pedersen SJ : Effect of standing or walking at a workstation on cognitive function a randomized counterbalanced trial. Hum Factors $2016 ; 58: 140-149$

19) Basso JC, Shang A, Elman M, Karmouta R, Suzuki WA : Acute exercise improves prefrontal cortex but not hippocampal function in healthy adults. J Int Neuropsychol Soc $2015 ; 21: 791-801$

20) Howie EK, Schatz J, Pate RR : Acute effects of classroom exercise breaks on executive function and math performance : a dose-response study. Res Q Exerc Sport 2015;86:217-224

21) Vanderbeken I, Kerckhofs E : A systematic review of the effect of physical exercise on cognition in stroke and traumatic brain injury patients. NeuroRehabilitation $2017 ; 40: 33-48$

22) Bateman A, Culpan FJ, Pickering AD, Powell JH, Scott OM, Greenwood RJ : The effect of aerobic training on rehabilitation outcomes after recent severe brain injury : a randomized controlled evaluation. Arch Phys Med Rehabil 2001; 82 : 174-182

23) McMillan T, Robertson IH, Brock D, Chorlton L : Brief mindfulness training for attentional problems after traumatic brain injury : A randomised control treatment trial. Neuropsychol Rehabil 2002; 12 : 117-125

24) Chin LM, Keyser RE, Dsurney J, Chan L : Improved cognitive performance following aerobic exercise training in people with traumatic brain injury. Arch Phys Med Rehabil 2015 ; 96 : 754-759

25) Nilsson L, Carlsson J, Danielsson A, Fugl-Meyer A, Hellström K, Kristensen L, Sjölund B, Sunnerhagen KS, Grimby G : Walking training of patients with hemiparesis at an early stage after stroke:A comparison of walking training on a treadmill with body weight support and walking training on the ground. Clin Rehabil $2001 ; 15: 515-527$

26) Fang Y, Chen X, Li H, Lin J, Huang R, Zeng I : A study on additional early physiotherapy after stroke and factors affecting functional recovery. Clin Rehabilil $2003 ; 17: 608-617$

27) Studenski S, Duncan PW, Perera S, Reker D, Lai SM, Richards L : Daily functioning and quality of life in a randomized controlled trial of therapeutic exercise for subacute stroke survivors. Stroke $2005 ; 36$ : 1764-1770

28) Ploughman M, McCarthy J, Bossé M, Sullivan HJ, Corbett D : Does treadmill exercise improve performance of cognitive or upper-extremity tasks in people with chronic stroke? A randomized crossover trial. Arch Phys Med Rehabil 2008; 89 : 2041-2047

29) Quaney BM, Boyd LA, McDowd JM, Zahner LH, He J, Mayo MS, Macko RF : Aerobic exercise improves cognition and motor function poststroke. Neurorehabil Neural Repair $2009 ; 23: 879-885$

30) Moore SA, Hallsworth K, Jakovljevic DG, Blamire AM, He J, Ford GA, Rochester L, Trenell MI : Effects of community exercise therapy on metabolic, brain, physical, and cognitive function following stroke : A randomized controlled pilot trial. Neurorehabil Neural Repair $2015 ; 29:$ 623-635

31) Pyöriä O, Talvitie U, Nyrkkö $H$, Kautiainen $H$, Pohjolainen T, Kasper V: The effect of two physiotherapy approaches on physical and cognitive functions and independent coping at home in stroke rehabilitation. A preliminary follow-up study. Disabil Rehabil 2007 ; 29 : 503-511

32) El-Tamawy MS, Abd-Allah F, Ahmed SM, Darwish $\mathrm{MH}$, Khalifa HA : Aerobic exercises enhance cognitive functions and brain derived neurotrophic factor in ischemic stroke patients. NeuroRehabilitation $2014 ; 34: 209-213$

33) Kluding PM, Tseng BY, Billinger SA : Exercise and executive function in individuals with chronic stroke : A pilot study. J Neurol Phys Ther 2011 ; 35 : 11-17

34) Marzolini S, Oh P, McIlroy W, Brooks D : The effects of an aerobic and resistance exercise training program on cognition following stroke. Neurorehabil Neural Repair $2013 ; 27$ : 392-402 